\title{
KUALITAS LABA DAN PENGUNGKAPAN SUKARELA DAMPAKNYA TERHADAP BIAYA MODAL EKUITAS MELALUI ASIMETRI INFORMASI
}

\author{
Ibnu Abni Lahaya \\ Departemen Akuntansi Fakultas Ekonomi dan Bisnis Universitas Mulawarman \\ Jl. Tanah Grogot No.1 Kampus Gn.Kelua, Samarinda, 75119, Indonesia
}

\begin{abstract}
Keywords: asymmetry information, earning quality, cost of equity capital, voluntary disclosure

JEL Classification: D23, D82, G30

This study aimed to examine the effect of earning quality and voluntary disclosure on cost of equity capital with information asymmetry as an intervening variable. The study was conducted by analyzing 118 manufacturing companies listed in Indonesia Stock Exchange during the years 2013 to 2015 by using path analysis. The results of this study indicate that information asymmetry mediating the relationship of earnings quality and voluntary disclosure on cost of equity capital. These findings indicate that the company may affect the cost of equity capital by minimize the degree of information asymmetry with improving earning quality and expanding voluntary disclosure. The reduced cost of equity capital caused by low rate of return required by investors because the information presented to minimize the level of information asymmetry. This study indicates that information has an important role to lowering information asymmetry and cost of equity capital, as indicated by the response of investors and other market participants to the information disclosed by company.
\end{abstract}

Kata kunci: asimetri informasi, kualitas laba, biaya modal ekuitas, pengungkapan sukarela

\begin{tabular}{l} 
ABSTRAK \\
\hline Penelitian ini bertujuan untuk menguji pengaruh kualitas laba dan pengungkapan \\
sukarela terhadap biaya modal ekuitas dengan asimetri informasi sebagai variabel inter- \\
vening. Studi ini dilakukan pada 118 perusahaan manufaktur yang ditentukan dengan \\
metode purposive sampling dengan periode amatan tahun 2013-2015 menggunakan \\
analisis jalur. Hasil penelitian ini menunjukkan bahwa asimetri informasi memediasi \\
hubungan kualitas laba dan pengungkapan sukarela terhadap biaya modal ekuitas. \\
Temuan ini mengindikasikan bahwa perusahaan dapat memengaruhi biaya modal \\
ekuitas dengan meningkatkan kualitas laba dan memperluas pengungkapan sukarela. \\
Berkurangnya biaya modal ekuitas disebabkan rendahnya tingkat imbal saham yang \\
dipersyaratkan investor dikarenakan informasi yang tersaji meminimalisir tingkat \\
asimetri informasi yang terjadi. Penelitian ini menunjukkan informasi memiliki peranan \\
yang sangat penting dalam menurunkan biaya modal ekuitas sebagaimana investor dan \\
pelaku pasar lainnya merespon terhadap informasi yang diungkapkan perusahaan.
\end{tabular}




\section{Kualitas Laba dan Pengungkapan Sukarela Dampaknya terhadap Biaya Modal Ekuitas Melalui Asimetri Informasi Ibnu Abni Lahaya}

Beberapa penelitian menunjukkan bahwa besaran biaya modal ekuitas sangat ditentukan oleh informasi (Botosan, 1997; Francis et al., 2004, 2005; Bhattacharya et al., 2011; Bhattacharya et al., 2012). Bhattacharya et al. (2012) menyatakan bahwa salah satu risiko investasi adalah terdapatnya ketidakpastian atau ketidaktepatan informasi sebagai akibat adanya asimetri informasi. Asimetri informasi membuat investor bertindak dengan keputusan investasi yang berbeda dikarenakan investor dihadapkan pada permasalahan atas ketidakjelasan risiko dan manfaat atas investasinya.

Salah satu tindakan yang dapat dilakukan untuk mengatasi asimetri informasi ialah dengan meningkatkan kualitas dan memperluas informasi yang tersaji dalam pengungkapan (disclosure). Kualitas informasi yang harus menjadi perhatian perusahaan ialah informasi laba. Kualitas laba dapat dijadikan sebagai proksi risiko informasi yang terjadi antara manajer dan investor (Enayati, 2013). Salah satu pengukur kualitas akrual dalam laba ialah dengan mengetahui tingkat akrual diskresioner. Ukuran ini menunjukkan bahwa laba dikatakan lebih berkualitas apabila nilai absolut akrual diskresionernya semakin kecil. Semakin tinggi tingkat akrual diskresioner menunjukkan semakin rendah nilai kualitas laba (Ajward \& Takehara, 2011). Hasil penelitian Apergis et al. (2013) menunjukkan bahwa investor tidak dapat sepenuhnya memaknai akrual diskresioner dalam pengumuman informasi laba perusahaan publik sebagai alat untuk mengatasi risiko asimetri informasi sehingga menurunkan keuntungan investor tersebut. Kualitas laba yang buruk akan menyebabkan peningkatan asimetri informasi dan menghasilkan biaya modal ekuitas yang besar, sedangkan penurunan asimetri informasi akan menurunkan biaya modal ekuitas (Sofian et al., 2011).

Selain itu, informasi yang diungkapkan oleh pihak manajemen perusahaan melalui pengungkapan sukarela merupakan salah satu faktor yang memengaruhi biaya modal ekuitas (Indayani \&
Mutia, 2013). Informasi yang tersaji dalam pengungkapan sukarela memberikan tambahan informasi bagi investor sehingga menurunkan tingkat asimetri informasi yang terjadi sehingga dapat menarik lebih banyak investor yang bersifat jangka panjang (Petrova et al., 2011). Juniarti \& Yunita (2003) menyatakan bahwa tingkat pengungkapan yang tinggi menunjukkan tidak ada informasi yang disembunyikan oleh perusahaan sehingga estimasi investor atas risiko yang ada pada perusahaan rendah, dan tingkat pengembalian yang diharapkan oleh investor juga rendah (Juniarti \& Yunita, 2003).

Berdasarkan latar belakang dan mengacu pada penelitian-penelitian sebelumnya, maka penelitian ini secara umum bertujuan untuk mengetahui pengaruh pengungkapan terhadap biaya modal ekuitas dengan asimetri informasi sebagai pemediasi (variabel intervening).

Agency theory menjelaskan proses terjadinya asimetri informasi di dalam suatu perusahaan. Pemisahan antara pemilik sebagai prinsipal dan manajer sebagai agen yang menjalankan perusahaan memunculkan permasalahan agensi karena tiap-tiap pihak akan selalu berusaha untuk memaksimalkan fungsi utilitas yang dimilikinya. Jensen \& Meckling (1976) menyatakan bahwa hubungan keagenan sebagai kontrak dengan satu orang atau lebih yang bertindak sebagai prinsipal (pemegang saham/shareholder) menunjuk orang lain sebagai agen (manajer) untuk melakukan jasa bagi kepentingan prinsipal, termasuk mendelegasikan kekuasaan dalam pengambilan keputusan kepada agen. Investor yang tidak terinformasi atau memiliki informasi yang kurang akan bertindak dengan asumsi risiko yang meningkat (tinggi) (Wang, 1993).

Pecking order theory mengasumsikan bahwa perusahaan bertujuan untuk memaksimumkan kesejahteraan pemegang saham. Myers (1984) menyatakan bahwa perusahaan lebih menyukai internal financing yaitu pendanaan dari hasil operasi perusahaan yang berwujud laba ditahan. Apabila 


\section{Jurnal Keuangan dan Perbankan | KEUANGAN}

Vol. 21, No. 2, Mei 2017: 188-199

diperlukan pendanaan eksternal maka perusahaan akan menerbitkan sekuritas paling aman terlebih dahulu yaitu dimulai dengan penerbitan obligasi, kemudian diikuti oleh sekuritas yang berkarakteristik opsi, baru akhirnya apabila masih belum mencukupi akan menerbitkan saham baru. Jadi urutan penggunaan sumber pendanaan dengan pengacu pada Pecking order theory adalah internal fund (dana internal), debt (hutang) dan equity (ekuitas). Dana internal lebih disukai dari dana eksternal karena dana internal memungkinkan perusahaan untuk tidak perlu "membuka diri lagi" dari sorotan pemodal luar. Di samping itu pengaruh asimetri informasi dan biaya penerbitan saham cenderung mendorong perilaku pecking order (Myers, 1984; Baskin, 1989)

Pengungkapan sukarela adalah pengungkapan yang dilakukan perusahaan di luar apa yang diwajibkan oleh standar akuntansi atau peraturan badan pengawas (Suwardjono, 2010: 583). Di Indonesia, pengungkapan dalam laporan tahunan bagi perusahaan yang terdaftar dalam Bursa Efek Indonesia (BEI) harus mengacu pada peraturan Standar Akuntansi Keuangan yang berlaku yang diterbitkan oleh DSAK IAI serta peraturan nomor X.K.6 tahun 2012 tentang Kewajiban Penyampaian Laporan Tahunan bagi Emiten dan Perusahaan Publik dan peraturan nomor VIII.G.7 tentang Pedoman Penyajian Laporan Keuangan yang diterbitkan oleh Otoritas Jasa Keuangan (OJK), yang telah menggantikan Bapepam-LK terhitung sejak 1 Januari 2013. Pengungkapan sukarela ditentukan sesuai dengan kebijakan perusahaan untuk memberikan informasi yang lebih relevan dan meningkatkan kinerja perusahaaan di bursa saham (Dahlan, 2003)

Kualitas laba dipandang sebagai ukuran atau fungsi dari kinerja perusahaan secara fundamental (Dechow et al., 2010). Kualitas laba sangat dipengaruhi oleh tingkat kualitas akrual yang lebih menyediakan informasi mengenai kinerja keuangan perusahaan. Akrual diskresioner merupakan ke- bijakan akrual yang dilakukan dengan campur tangan atau intervensi manajemen perusahaan untuk memengaruhi pengakuan pendapatan dan beban perusahaan. Bentuk kesalahan dalam akrual, baik disengaja maupun tidak disengaja, melemahkan hubungan antara laba tahun berjalan dan arus kas masa depan sehingga mengurangi kualitas laba (Bachtiar, 2007; Abbasi, 2013). Laba dikatakan lebih berkualitas apabila nilai absolut akrual diskresionernya semakin kecil. Semakin tinggi tingkat akrual diskresioner, semakin rendah nilai kualitas laba (Ajward \& Takehara, 2011).

Biaya modal ekuitas merupakan biaya yang dikeluarkan oleh perusahaan yang memperoleh dana dengan menjual saham biasa atau menggunakan laba yang ditahan untuk investasi (Putri, 2013). Pada sisi lain, biaya modal ekuitas sering dikaitkan dengan tingkat return (imbal saham) atau keuntungan yang diharapkan investor sebagai penyedia dana. Pengungkapan akan meningkatkan likuiditas harga saham di pasar sebagai akibat menurunnya asimetri informasi sehingga akan menurunkan biaya modal ekuitas (Diamond \& Verrecchia, 1991). Logika dari pandangan ini menunjukkan bahwa pengungkapan yang lebih besar mengurangi asimetri informasi antara manajer dan investor. Pengungkapan yang lebih luas menaikkan likuiditas pasar saham, dengan demikian menurunkan biaya modal ekuitas, baik melalui menurunnya biaya-biaya transaksi atau melalui meningkatnya permintaan sekuritas perusahaan.

\section{PENGEMBANGAN HIPOTESIS}

\section{Pengaruh kualitas laba dan pengungkapan sukarela terhadap asimetri informasi}

Dechow et al. (2010) menyatakan bahwa kualitas laba yang tinggi lebih menyediakan informasi mengenai kinerja keuangan perusahaan yang relevan untuk pengambilan keputusan bagi beberapa pihak tertentu. Pendapat ini didukung oleh Ajward \& Takehara (2011) bahwa laba sebagai 


\section{Kualitas Laba dan Pengungkapan Sukarela Dampaknya terhadap Biaya Modal Ekuitas Melalui Asimetri Informasi Ibnu Abni Lahaya}

elemen utama informasi akuntansi dalam efisiensi dan efektivitas pasar modal sehingga kualitas laba harus ditingkatkan selain sebagai sinyal kepada investor mengenai kondisi perusahaan, juga dalam mereduksi asimetri informasi. Bhattacharya et al. (2011) menjelaskan bahwa salah satu konsekuensi dalam menyajikan kualitas laba yang buruk ialah memperburuk tingkat asimetri informasi. Bachtiar (2007) menemukan bahwa manajemen laba berpengaruh terhadap tingkat asimetri informasi yang terjadi selama periode pengumuman. Tingkat manajemen laba yang dilakukan oleh manajemen, terlihat dalam akrual diskresioner, menyebabkan meningkatnya asimetri informasi, sebagaimana tercermin dalam bid-ask spread.

$\mathrm{H}_{1}$ : kualitas laba berpengaruh langsung dan negatif terhadap asimetri informasi.

Bernardi et al. (2009) menyatakan bahwa pengungkapan yang luas dapat membatasi sikap manajer yang oportunistik yang dapat merugikan pemegang saham dan stakeholder lainnya. Juniarti \& Yunita (2003) menyatakan bahwa tingkat pengungkapan yang tinggi mengurangi tingkat asimetri informasi, yang menunjukkan bahwa tidak ada informasi yang disembunyikan oleh perusahaan sehingga laporan keuangan yang disajikan oleh perusahaan transparan. Diamond \& Verrecchia (1991) menyatakan bahwa asimetri informasi bisa berkurang apabila perusahaan melaksanakan kebijakan pengungkapan yang luas. Botosan (1997) mengungkapkan bahwa tingkat kelengkapan pengungkapan yang komprehensif atau tinggi akan memperkecil asimetri informasi. Hamrouni \& Solonandrasana (2013) menyatakan bahwa manfaat pengungkapan sukarela dalam laporan tahunan dengan tingkat informasi sukarela yang tinggi berhubungan dengan tingkat asimetri informasi yang rendah di pasar modal.

$\mathrm{H}_{2}$ : pengungkapan sukarela berpengaruh langsung dan negatif terhadap asimetri informasi
Lambert et al. (2007) menunjukkan bahwa kualitas informasi akuntansi memengaruhi biaya modal ekuitas perusahaan, baik secara langsung dengan memengaruhi persepsi pelaku pasar mengenai distribusi arus kas masa depan, maupun secara tidak langsung dengan memengaruhi keputusan yang dapat mengubah distribusi arus kas masa depan. Temuan Utami (2005) memberikan bukti empiris bahwa investor mengantisipasi informasi yang terkait dengan tingkat akrual diskresioner dengan tingkat imbal hasil saham yang dipersyaratkan. Semakin tinggi tingkat akrual diskresioner, hal itu menunjukkan tingginya potensi manajemen laba dan menyebabkan meningkatnya biaya modal ekuitas. Leuz \& Verrecchia (2004) mengungkapkan dalam hasil penelitiannya bahwa peranan laporan kinerja (misalnya laba) ialah menyelaraskan perusahaan dan investor terkait dengan investasi modal.

$\mathrm{H}_{3}$ : kualitas laba berpengaruh langsung dan positif terhadap biaya modal ekuitas

Petrova et al. (2011) mengungkapkan bahwa biaya modal ekuitas dapat diturunkan dengan meningkatkan pengungkapan sukarela. Hasil penelitian Juniarti \& Yunita (2003) menunjukkan tingkat pengungkapan berpengaruh negatif terhadap asimetri informasi. Marquadt \& Wieldman (1998) juga menyatakan bahwa tindakan manajer dalam memberikan informasi yang luas untuk meminimalkan tingkat asimetri informasi berkorelasi dengan rendahnya biaya modal. Francis et al. (2005) memberikan bukti empiris bahwa perusahaan dengan kebutuhan keuangan eksternal yang tinggi secara umum memilih untuk memperluas pengungkapan informasi guna mengurangi biaya modal ekuitas. Temuan ini sejalan dengan

$\mathrm{H}_{4}$ : pengungkapan sukarela berpengaruh langsung dan negatif terhadap biaya modal ekuitas 


\section{Jurnal Keuangan dan Perbankan | KEUANGAN}

Vol. 21, No. 2, Mei 2017: 188-199

Keberadaan asimetri informasi dapat berimbas terhadap besaran biaya modal ekuitas yang ditanggung perusahaan, dengan tingkat persaingan dalam pasar modal memainkan peranan yang penting (Lambert et al., 2011). He et al. (2013) dan Apergis et al. (2013) mengemukakan bahwa asimetri informasi memang meningkatkan biaya modal ekuitas, terletak pada kelemahan informasi yang dimiliki oleh investor sehingga meningkatkan risiko dan investor membebankannya pada tingkat imbal saham yang dipersyaratkan. Khomsiyah \& Susanti (2003) menyatakan bahwa semakin banyak informasi yang disembunyikan oleh pihak agen, maka akan semakin tinggi risiko yang harus ditanggung oleh pemilik modal. Keberadaan investor yang kurang terinformasi meningkatkan premi risiko pada saham (Wang, 1993). Hal ini berarti bahwa semakin kecil asimetri informasi yang terjadi di antara partisipan pasar modal, semakin kecil biaya modal ekuitas yang ditanggung oleh perusahaan.

$\mathrm{H}_{5}$ : asimetri informasi berpengaruh langsung dan positif terhadap biaya modal ekuitas

Kualitas laba, sebagai proksi risiko informasi, digunakan investor atau para pengguna laporan keuangan untuk menilai kinerja keuangan perusahaan, terutama dalam menentukan tingkat imbal saham yang dipersyaratkan. Lambert et al. (2007) menyatakan bahwa kualitas informasi akuntansi dapat memengaruhi persepsi dan tindakan pelaku pasar, baik secara langsung maupun tidak langsung. Laba tidak hanya memengaruhi imbal saham pasar, tetapi juga dapat mengurangi asimetri informasi di pasar modal (Lev, 1988). Bhattacharya et al. (2011) mengungkapkan bahwa kualitas laba yang buruk memiliki konsekuensi merugikan yaitu meningkatnya asimetri informasi sehingga menimbulkan biaya transaksi dan mengurangi likuiditas yang diharapkan atas saham perusahaan. Akibatnya, investor akan merespon dengan menaikkan tingkat imbal saham yang dipersyaratkan untuk menutupi biaya yang telah mereka keluarkan. Ajward \& Takehara (2011) menyatakan bahwa sebagai elemen utama dalam informasi akuntansi dan sebagai sinyal mengenai kondisi perusahaan, laba juga berfungsi dalam mereduksi asimetri informasi.

$\mathrm{H}_{6}$ : asimetri informasi memediasi pengaruh kualitas laba terhadap biaya modal ekuitas

Investor sangat berhati-hati dalam pengambilan keputusan terkait risiko yang disebabkan oleh keberadaan asimetri informasi. Melalui kebijakan pengungkapan yang luas, manajemen memberikan informasi yang lebih lanjut mengenai keadaan perusahaan. Penelitian Botosan (1997) menunjukkan bahwa tingkat kelengkapan pengungkapan yang semakin komprehensif atau tinggi akan memperkecil asimetri informasi. Easley \& O'Hara (2004) menyatakan bahwa perusahaan dapat memengaruhi biaya modal ekuitas dengan memengaruhi presisi dan jumlah informasi yang tersedia bagi investor. Laporan keuangan yang transparan menyebabkan estimasi investor atas risiko yang ada pada perusahaan rendah, sehingga tingkat pengembalianyang diharapkan oleh investor juga rendah, yang pada gilirannya biaya modal ekuitas perusahaan juga rendah (Juniarti \& Yunita, 2003).

$\mathrm{H}_{7}$ : asimetri informasi memediasi pengaruh pengungkapan sukarela terhadap biaya modal ekuitas

\section{METODE}

Penelitian ini menggunakan tiga periode waktu yaitu tahun 2013 hingga tahun 2015 dengan populasi penelitian perusahaan publik sektor manufaktur di Indonesia yang terdaftar di Bursa Efek Indonesia. Pemilihan sampel dilakukan dengan menggunakan purposive sampling method sebagai berikut. 


\section{Kualitas Laba dan Pengungkapan Sukarela Dampaknya terhadap Biaya Modal Ekuitas Melalui Asimetri Informasi}

Ibnu Abni Lahaya

Tabel 1. Penentuan Sampel Penelitian

\begin{tabular}{lcc}
\hline \multicolumn{1}{c}{ Keterangan } & Jumlah \\
\hline Perusahaan manufaktur terdaftar di BEI periode tahun 2013-2015 & 139 \\
$\begin{array}{l}\text { Perusahaan manufaktur yang tidak berturut-turut terdaftar di BEI periode tahun 2013-2015 (karena } \\
\text { delisting atau terdaftar setelah 2013) }\end{array}$ & $(10)$ \\
Perusahaan manufaktur yang terdaftar di BEI periode tahun 2013-2015 memiliki total ekuitas negatif & $(11)$ \\
Total perusahaan yang dapat dijadikan sampel & 118 \\
Total observasi (118 perusahaan x $\mathbf{3}$ tahun) & $\mathbf{3 5 4}$ \\
\hline
\end{tabular}

Kualitas laba merupakan tingkat baik-buruknya atau taraf (derajat) laba dan dapat merefleksikan dampak ekonomis yang sesungguhnya dari suatu transaksi. Salah satu proksi untuk mengukur kualitas laba ialah mengukur tingkat akrual diskresioner (Bhattacharya et al., 2011; Bhattacharya et al., 2012) dengan menggunakan model Kothari et al. (2005).

Pengungkapan sukarela merupakan pengungkapan informasi yang dilakukan oleh perusahaan tanpa diharuskan oleh peraturan yang berlaku. Pengungkapan sukarela yang digunakan dalam penelitian ini yaitu item-item pengungkapan sukarela yang di adopsi berdasarkan penelitian sebelumnya yaitu Francis et al. (2008) dengan penyesuaian terhadap Standar Akuntansi Keuangan yang berlaku yang diterbitkan oleh DSAK IAI serta peraturan nomor X.K.6 tahun 2012 tentang Kewajiban Penyampaian Laporan Tahunan bagi Emiten dan Perusahaan Publik dan peraturan nomor VIII.G.7 tentang Pedoman Penyajian Laporan Keuangan.

Asimetri informasi adalah kesenjangan informasi yang terjadi karena adanya konflik kepentingan antara manajer, pemegang saham dan stakeholder lainnya. Asimetri informasi diukur menggunakan bid-ask spread (Putri, 2013).

Biaya modal ekuitas adalah biaya riil yang harus dikeluarkan perusahaan untuk memperoleh dana investasi atau operasi perusahaan. Biaya modal ekuitas dihitung berdasarkan tingkat diskonto (dari) future cash flow menggunakan model Ohlson (Botosan, 1997; Utami, 2005; Purwanto, 2012).

Teknik analisis data yang digunakan dalam pengujian hipotesis ialah analisis regresi berganda dan analisis jalur dengan alat bantu SPSS 23. Adapun model analisis jalur lengkap digambarkan sebagai berikut.

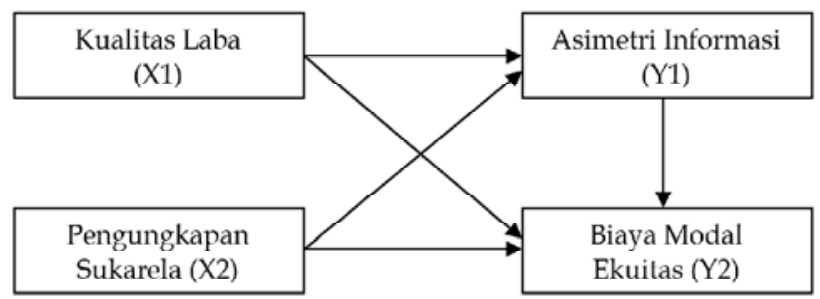

Gambar 1. Diagram Jalur Penelitian

Persamaan regresi dalam penelitian ini ditunjukkan seperti berikut.

$$
\begin{aligned}
& \text { SPREAD }=\alpha+\beta_{1} \text { DA }+\beta_{2} \text { PS }+\mathrm{e}_{1} \ldots \ldots \ldots \ldots \ldots \ldots \ldots \ldots \ldots \\
& \text { COEC }=\alpha+\beta_{3} \text { DA }+\beta_{4} \text { PS }+\beta_{5} \text { SPREAD }+\mathrm{e}_{2}
\end{aligned}
$$

Keterangan:

DA $=$ Akrual Diskresioner

PS = Pengungkapan Sukarela

SPREAD = Asimetri Informasi

COEC = Biaya Modal Ekuitas 


\section{Jurnal Keuangan dan Perbankan | KEUANGAN}

Vol. 21, No. 2, Mei 2017: 188-199

HASIL

Nilai variabel akrual diskresioner berada pada kisaran -1,200 dan 1,390. Serta nilai rata-rata akrual diskresioner sebesar 0,026 . Nilai variabel pengungkapan sukarela berada pada kisaran 21,7\% dan $60,9 \%$. Keseluruhan data variabel pengungkapan sukarela memiliki mean sebesar 0,392 atau $39,2 \%$ dan standar deviasi sebesar 0,090 atau 9\%. Nilai variabel asimetri informasi berada pada kisaran 47,7\% dan 97,7\%. Keseluruhan data variabel kualitas laba ini memiliki mean sebesar 0,742 atau $74,2 \%$ dan standar deviasi sebesar 0,070 atau $7 \%$. Nilai variabel biaya modal ekuitas berada pada kisaran-1,152 dan 5,179. Keseluruhan data variabel biaya modal ekuitas ini memiliki mean sebesar 1,160 dan standar deviasi sebesar 0,881 .

Setelah dilakukan uji asumsi klasik, terbukti bahwa model regresi 1 dan 2 lolos dari (1) uji nor- malitas (menggunakan uji Kolmogorov Smirnov untuk model regresi pertama sebesar 1,130 dan model regresi kedua sebesar 1,589); (2) multikolinearitas (model regresi pertama, nilai VIF untuk akrual diskresioner sebesar 1,000 dan pengungkapan sukarela sebesar 1,000 serta pada model regresi kedua nilai VIF akrual diskresioner sebesar 1,188, pengungkapan sukarela sebesar 1,025, dan asimetri informasi sebesar 1.212); (3) uji autokorelasi (terdapat gejala autokorelasi positif, model 1 dengan nilai 1,803 <1,819 dan model 2 dengan nilai $1,789<1,813$, namun dapat diabaikan karena mengunakan data cross sectional) dan (4) heterokedastisitas (model regresi pertama, nilai signifikansi untuk akrual diskresioner sebesar 0,785 dan pengungkapan sukarela sebesar 0,317 serta pada model regresi kedua nilai signifikansi akrual diskresioner sebesar 0,844, pengungkapan sukarela sebesar 0,607, dan asimetri informasi sebesar 0.164).

Tabel 2. Analisis Statistik Deskriptif Variabel Penelitian

\begin{tabular}{lrrrrr}
\hline & N & Minimum & Maximum & Mean & Std. Deviation \\
\hline Akrual Diskresioner & 354 & $-0,1996$ & 0,3895 & 0,026049 & 0,1987689 \\
Pengungkapan Sukarela & 354 & 0,2174 & 0,6087 & 0,390813 & 0,0901601 \\
Asimetri Informasi & 354 & 0,4770 & 0,9770 & 0,741527 & 0,0703334 \\
Biaya Modal Ekuitas & 354 & $-1,1517$ & 3,1794 & $1,159773 \mathrm{E} 0$ & 0,8805461 \\
\hline
\end{tabular}

Tabel 3. Hasil Analisis Regresi Berganda

\begin{tabular}{|c|c|c|c|c|c|}
\hline Model & Variabel Dependen & Variabel Independen & B & $\begin{array}{l}\text { Koefisien } \\
\text { Jalur (Beta) }\end{array}$ & $\begin{array}{l}\text { Signifikansi } \\
\text { (p-value) }\end{array}$ \\
\hline \multirow{4}{*}{1} & \multirow{2}{*}{ Asimetri Informasi } & Akrual Diskresioner & 0.139 & 0.394 & 0.000 \\
\hline & & Pengungkapan Sukarela & -0.113 & -0.145 & 0.003 \\
\hline & \multirow{7}{*}{ Biaya Modal Ekuitas } & $\mathrm{R}^{2}=0.175$ & $\mathrm{~F}=37.284$ & & $\alpha=0.782$ \\
\hline & & Adj. $R^{2}=0.171$ & \multicolumn{3}{|c|}{ Sig. $F=0.000$ (probabilitas 0.05$)$} \\
\hline \multirow{5}{*}{2} & & Akrual Diskresioner & 1.516 & 0.342 & 0.000 \\
\hline & & Pengungkapan Sukarela & -0.277 & 0.028 & 0.558 \\
\hline & & Asimetri Informasi & 2.282 & 0.182 & 0.001 \\
\hline & & $\mathrm{R}^{2}=0.201$ & $F=29.430$ & & $\alpha=-0.464$ \\
\hline & & Adj. $R^{2}=0.195$ & \multicolumn{3}{|c|}{ Sig. $F=0.000$ (probabilitas 0.05 ) } \\
\hline
\end{tabular}




\section{Kualitas Laba dan Pengungkapan Sukarela Dampaknya terhadap Biaya Modal Ekuitas Melalui Asimetri Informasi}

Ibnu Abni Lahaya

Adapun hasil output analisis regresi untuk ditunjukkan pada Tabel 3.

Adapun persamaan regresi sebagai berikut:

$$
\begin{aligned}
Y_{1}= & 0,782+0,139 X_{1}-0,113 X_{2}+e_{1} \text { atau } Y_{1}=0,394 \\
& X_{1}-0,145 X_{2}+e_{1} \\
Y_{2}= & -0,464+1,156 X_{1}-0,277 X_{2}+2,282 Y_{1}+e_{2} \text { atau } \\
& Y_{2}=0,342 X_{1}-0,028 X_{2}+0,182 Y_{1}+e_{2}
\end{aligned}
$$

Hasil uji t untuk koefisien jalur menyatakan bahwa kualitas laba yang diproksikan dengan akrual diskresioner dengan koefisien jalur 0,394 berpengaruh positif terhadap asimetri informasi dengan $p$-value sebesar $0,000(<5 \%)$.

Hasil uji t untuk koefisien jalur menyatakan bahwa pengungkapan sukarela dengan koefisien jalur $-0,113$ berpengaruh negatif terhadap asimetri informasi dengan $p$-value sebesar 0,003 $(<5 \%)$.

Hasil uji t untuk koefisien jalur menyatakan bahwa akrual diskresioner dengan koefisien jalur 0,342 berpengaruh positif terhadap biaya modal ekuitas dengan $p$-value sebesar 0,000 (<5\%).

Hasil uji t menyatakan bahwa pengungkapan sukarela dengan koefisien jalur $-0,028$ berpengaruh negatif namun tidak signifikan terhadap biaya modal ekuitas dengan $p$-value sebesar 0,558 (> 5\%).

Hasil uji t untuk koefisien jalur menyatakan bahwa asimetri informasi dengan koefisien jalur 0,182 berpengaruh positif terhadap biaya modal ekuitas dengan $p$-value sebesar 0,001 (<5\%).

\section{PEMBAHASAN}

Hasil penelitian menunjukkan bahwa kualitas laba yang diproksikan dengan akrual diskresioner berpengaruh positif terhadap asimetri informasi. Hasil ini menunjukkan kualitas laba yang diukur dengan menggunakan diskresioner akrual berpengaruh positif pada tingkat asimetri informasi yang tercermin dalam bid-ask spread. Dengan kata lain, kualitas laba yang semakin tinggi akan menu- runkan asimetri informasi. Sebaliknya, kualitas laba yang rendah akan meningkatkan asimetri informasi. Hasil penelitian ini konsisten dengan penelitian Bachtiar (2007), Jayaraman (2008), Ajward \& Takehara (2011), Bhattacharya et al. (2011), Brown \& Hillegeist (2007) dan Bhattacharya et al. (2012).

Hasil penelitian menunjukkan bahwa pengungkapan sukarela dengan berpengaruh negatif terhadap asimetri informasi. Hasil ini menunjukkan bahwa luas ungkapan yang dilakukan manajemen akan menurunkan tingkat asimetri informasi. Hasil penelitian ini konsisten dengan penelitian Diamond \& Verrecchia (1991), Botosan (1997), Juniarti \& Yunita (2003), Benardi et al. (2009), Hanni (2010), Hamrouni \& Solonandrasana (2013), dan Putri (2013).

Hasil penelitian menyatakan bahwa akrual diskresioner berpengaruh positif terhadap biaya modal ekuitas. Hasil ini menunjukkan bahwa kualitas laba berpengaruh negatif terhadap biaya modal ekuitas. Dengan kata lain, kualitas laba yang semakin tinggi dengan tingkat akrual diskresioner yang rendah akan direspon oleh investor dengan menurunkan tingkat imbal saham yang dipersyaratkan. Semakin kecil tingkat imbal saham yang dipersyaratkan, biaya modal ekuitas yang dikeluarkan perusahaan akan menurun. Hasil penelitian ini konsisten dengan penelitian Leuz dan Verrecchia (2004), Utami (2005), Francis et al. (2005), Lambert et al. (2007), Bhattacharya et al. (2011), dan Bhattacharya et al. (2012).

Hasil penelitian menyatakan bahwa pengungkapan sukarela berpengaruh negatif namun tidak signifikan terhadap biaya modal ekuitas. Hasil ini tidak konsisten dengan penelitian Diamond \& Verrecchia (1991), Botosan (1997), Marquadt \& Wieldman (1998), Juniarti \& Yunita (2003), Easley \& O'Hara (2004), Francis et al. (2005), dan Petrova et al. (2011). Murni (2003) menyatakan bahwa luas pengungkapan sukarela yang disampaikan manajemen masih belum memadai sehingga tidak memperoleh dampak menurunnya biaya modal ekuitas. 


\section{Jurnal Keuangan dan Perbankan | KEUANGAN}

Vol. 21, No. 2, Mei 2017: 188-199

Hasil penelitian menyatakan bahwa asimetri informasi berpengaruh positif terhadap biaya modal ekuitas. Hasil ini mengindikasikan bahwa keberadaan asimetri informasi menimbulkan ketidakjelasan risiko dan manfaat investasi pada investor sehingga menimbulkan keraguan investor atas investasinya. Investor merespon dan bertindak dengan menaikkan tingkat imbal saham yang dipersyaratkannya untuk menghindari risiko yang akan ditanggungnya pada masa mendatang. Hasil penelitian ini konsisten dengan penelitian yang dilakukan oleh Ammihud dan Mendelson (1986), Wang (1993), Khomsiyah dan Susanti (2003), Lambert et al. (2011), Purwanto (2012), He et al. (2013), Apergis et al. (2013), dan Nuryaman (2014).

Untuk pengaruh tidak langsung dapat dilihat pada Tabel 4 berikut.

Berdasarkan hasil analisis jalur, dapat diinterpretasikan bahwa asimetri informasi memediasi secara parsial pengaruh akrual diskresioner (kualitas laba) terhadap biaya modal ekuitas. Temuan dalam penelitian ini menunjukkan bahwa kualitas laba yang tinggi memberikan informasi lebih bagi investor terkait kinerja keuangan per- usahaan sehingga dapat memberikan keputusan investasi yang optimal. Lebih lanjut, asimetri informasi memediasi penuh pengaruh pengungkapan sukarela terhadap biaya modal ekuitas karena pengungkapan sukarela tidak memiliki pengaruh langsung terhadap biaya modal ekuitas namun pengungkapan sukarela dapat memengaruhi biaya modal ekuitas setelah memengaruhi asimetri informasi. Minimnya risiko dengan informasi tambahan menyebabkan investor bertindak dengan menurunkan imbal saham yang dipersyaratkan, atau dengan kata lain, biaya modal ekuitas yang ditanggung perusahaan semakin rendah

\section{SIMPULAN DAN SARAN}

\section{Simpulan}

Penelitian ini bertujuan untuk mengetahui pengaruh pengungkapan terhadap biaya modal ekuitas dengan asimetri informasi sebagai pemediasi (variabel intervening). Hasil penelitian ini menunjukkan bahwa perusahaan dapat memengaruhi tingkat biaya modal ekuitas dengan meminimalkan tingkat asimetri informasi melalui peningkatan kualitas laba dan memperluas peng-

Tabel 4. Pengaruh Antar Variabel Secara Langung, Tidak Langsung, dan Total Pengaruh

\begin{tabular}{lccc}
\hline \multicolumn{1}{c}{ Pengaruh Antarvariabel } & Pengaruh Langsung & $\begin{array}{c}\text { Pengaruh Tidak Langsung } \\
\text { (Melalui Asimetri } \\
\text { Informasi) }\end{array}$ & Total Pengaruh \\
\hline $\begin{array}{l}\text { Akrual Diskresioner } \\
\text { Asimetri Informasi }\end{array}$ & 0.394 & & 0.394 \\
$\begin{array}{l}\text { Pengungkapan Sukarela Asimetri } \\
\text { Informasi }\end{array}$ & -0.145 & & 0.145 \\
$\begin{array}{l}\text { Asimetri Informasi } \\
\text { Biaya Modal Ekuitas }\end{array}$ & 0.182 & $(0.394)^{*}(0.182)=0.072$ & $(0.342)+(0.072)$ \\
$\begin{array}{l}\text { Akrual Diskresioner } \\
\text { Biaya Modal Ekuitas }\end{array}$ & & & 0.182 \\
$\begin{array}{l}\text { Pengungkapan Sukarela } \\
\text { Biaya Modal Ekuitas }\end{array}$ & 0.342 & $(-0.145)^{*}(0.182)=-0.026$ & $(-0.028)+(-0.026)$ \\
\end{tabular}




\section{Kualitas Laba dan Pengungkapan Sukarela Dampaknya terhadap Biaya Modal Ekuitas Melalui Asimetri Informasi Ibnu Abni Lahaya}

ungkapan. Rendahnya asimetri informasi meningkatkan rasa aman dan kepercayaan investor terhadap perusahaan atas investasinya. Hasil penelitian ini menunjukkan bahwa informasi memiliki peranan yang sangat penting dalam menurunkan asimetri informasi dan biaya modal ekuitas.

\section{Saran}

Hasil penelitian ini diharapkan dapat memberikan memberikan tambahan kajian dalam literatur bidang akuntansi yang terkait dengan agency theory, pecking order theory, dan pengungkapan (disclosure). Temuan ini juga dapat memberikan masukan dalam pengembangan ilmu dan saran untuk menyosialisasikan kualitas laba sebagai proksi untuk asimetri informasi. Selain itu, hasil penelitian ini dapat menjadi masukan bagi perusahaan, dimana perusahaan dapat mengurangi biaya modal ekuitas melalui kebijakan pengungkapan yang lebih baik, yaitu dengan meningkatkan kualitas laba dan memperluas pengungkapan untuk meminimalkan asimetri informasi.

Untuk penelitian berikutnya diharapkan dapat mempertimbangkan beberapa keterbatasan dan saran berikut.

Penelitian ini hanya menggunakan pengukuran kualitas laba berdasarkan kualitas akrual yaitu akrual diskresioner. Penelitian berikutnya sebaiknya menambahkan komponen innate accruals dalam mengukur kualitas akrual laba. Selain itu, penelitian berikutnya juga dapat mempertimbangkan menggunakan proksi (atribut) kualitas laba lain, seperti persistance (persistensi), predictability (kemampuan memprediksi), dan smoothness.

Indeks pengungkapan sukarela yang digunakan dalam penelitian masih bersifat subjektif. Penelitian berikutnya dapat mengurangi masalah subjektivitas dengan melibatkan beberapa peneliti dalam menilai laporan tahunan dan memberikan bobot untuk setiap item pengungkapan sukarela.

\section{DAFTAR PUSTAKA}

Abbasi, S., Ajam, M., Peikarnegar, S., Mohamadi, K.2013. The Survey of Earning Quality to Information Asymmetry: Evidence from Tehran Stock Exchange. Switzerland Research Park Journal, 102(2): 63-73.

Ajward, A.R. \& Takehara, H. 2011. On the Relationship between Earning Quality and the Degree of Information Asymmetry: Evidence from Japan. Japan Journal of Finance, 31(1): 76-98.

Apergis, N., Artikis, G., Eleftheriou, Sofia., \& Sorros.J. 2013. Accounting Information, the Cost of Capital and Excess Stock Returns: The Role of Earnings Quality-Evidence from Panel Data. International Business Research, 5(2): 123-136.

Bachtiar, Y. 2007. Accrual and Information Asymetry. The $1^{\text {st }}$ Accounting Conference. Fakultas Ekonomi, Universitas Indonesia. Depok, 7 - 9 November 2007.

Baskin, J. 1989. Dividend Policy and the Volatility of Common Stock. Journal of Portfolio Management, 15(3): 19-25.

Benardi, M.K., Sutrisno, \& Assih, P. 2009. Faktor-faktor yang Mempengaruhi Luas Pengungkapan dan Implikasinya terhadap Asimetri Informasi. Prosiding, Simposium Nasional Akuntansi XII Palembang, 4-6 November 2009.

Bhattacharya, N., Ecker, F., Olsson, P., \& Schipper, K. 2012. Direct and Mediated Associations Among Earnings Quality, Information Asymmetry and the Cost of Equity. The Accounting Review, 87(2): 449-482.

Bhattacharya, N., Desai, H., \& Venkataraman, K. 2011. Earnings Quality and Information Asymmetry: Evidence From Trading Costs. Accepted Paper Series on SSRN. http://www.papers.ssrn.com. Diakses 27 Februari 2016.

Botosan, C. A. 1997. Disclosure Level and the Cost of Equity Capital. The Accounting Review, 72(1): 323-349.

Brown, S., \& Hillegeist, S.A. 2007. How Disclosure Quality Affects the Level of Information Asymmetry. Review of Accounting Studies, 12(2): 443-477.

Dahlan, A. 2003. Disclosure dan Corporate Governance: Suatu Tinjauan Teoritis. Jurnal TEMA, 4(1): 48-62. 


\section{Jurnal Keuangan dan Perbankan | KEUANGAN}

Vol. 21, No. 2, Mei 2017: 188-199

Dechow, P., Weili, G., \& Schrand, C. 2010. Understanding Earning Quality: A Review of the Proxies, Their Determinant and Their Consequences. Journal of Accounting and Economics, 50(2): 344-401.

Diamond, D. W. \& Verrecchia, R. E. 1991. Disclosure, Liquidity and the Cost of Capital.The Journal of Finance, 46(4): 1325-1359.

Easley, D. \& O'Hara, M. 2004. Information and the Cost of Capital. The Journal of Finance, 59(4): 1553-1583.

Enayati, E. 2013. Is Earnings Quality Used for Reacting to Capital Raising Announcement?. Journal of Basic and Applied Scientific Research, 3(2): 916-921.

Francis, J., LaFond, R., Olsson, P.M., \& Schipper, K. 2004. Costs of Equity and Earnings Attributes. The Accounting Review, 79(4): 967-1010.

Francis, J., LaFond, R., Olsson, P.M., \& Schipper. K. 2005. The Market Pricing of Accruals Quality. Journal of Accounting and Economics, 39(2): 295-327.

Francis, J., Nanda, D., \& Olsson, P. 2008. Voluntary Disclosure, Earnings Quality, and Cost of Capital. Journal of Accounting Research, 46(1): 112-134.

Hamrouni, A. \& Solonandrasana, B. 2013. Study of the Relationship Between the Extent of Voluntary Disclosure and Information Asymmetry in Stock Exchange Market. http://events.em-lyon.com/AFFI/Papers/13.pdf. Diakses 27 Februari 2016.

Hanni, S. 2010. Effects of Continuous and Voluntary Disclosures on Information Asymmetry: Evidence from the Financial Crisis. Accounting Master's Thesis. Department of Accounting and Finance. Aalto University School of Economics.

He, W.P., Lepone, A., \& Leung, H. 2013. Information Asymmetry and the Cost of Equity Capital. International Review of Economics and Finance, 27(2013): $611-620$.

Indayani \& Mutia, D. 2013. Pengaruh Informasi Asimetri dan Voluntary Disclosure terhadap Cost of Capital pada Perusahaan Manufaktur yang Terdaftar di Bursa Efek Indonesia. Jurnal Review Akuntansi dan Keuangan, 3(1): 373-382.

Jensen, M. C. \& Meckling, W.H. 1976. Theory of Firm: Manajerial Behavior, Agency Cost, and Owner- ship Structure. Journal of Financial Economic Vol.3 (1976): 305-360.

Juniarti \& Yunita, F. 2003. Pengaruh Tingkat Disclosure terhadap Biaya Ekuitas. Jurnal Akuntansi dan Keuangan, 5(2): 150-168.

Lambert, R., C. Leuz, dan R. Verrecchia. 2007. Accounting Information, Disclosure, and the Cost of Capital. Journal of Accounting Research, 45(2): 385-420.

Leuz, C., \& R. Verrecchia. 2004. Firms' Capital Allocation Choices, Information Quality, and The Cost of Capital. Working Paper on SSRN. http:// www.papers.ssrn.com Diakses 27 Februari 2016.

Lev, B. 1988. Toward a Theory of Equitable and Efficient Accounting Policy. The Accounting Review, 63(1): $1-22$.

Marquardt, C.A. \& Wiedman, C.I. 1998. Voluntary Disclosure, Information Asymmetry, and Insider Selling through Secondary Equity Offerings. Contemporary Accounting Research 15(4): 505 - 537

Myers, Stewart C. 1984. Corporate Financing and Investment Decisions When Firms Have Information That Investors Do Not Have. Journal of Financial Economics 13(2): 187-221.

Nuryaman. 2014. The Influence of Asymmetric Information on the Cost of Capital with the Earnings Management as Intervening Variable. Journal of Advanced Management Science, 2(1): 42-49.

Petrova, E. 2012. Relationship between Cost of Equity Capital and Voluntary Corporate Disclosure. International Journal of Economics and Finance, 4(3): 8396.

Purwanto, A. 2012. Pengaruh Manajemen Laba, Asymmetry Information, dan Pengungkapan Sukarela terhadap Biaya Modal. Prosiding. Simposium Nasional Akuntansi XV Banjarmasin, 20-23 September 2012.

Putri, E. 2013. Pengaruh Luas Pengungkapan Sukarela terhadap Biaya Modal dengan Asimetri Informasi sebagai Variabel Intervening: Studi Empiris pada Perusahaan Manufaktur yang Terdaftar di BEI. Skripsi Tidak Terpublikasi, Program Studi Akuntansi, Fakultas Ekonomi Universitas Negeri Padang. 
Kualitas Laba dan Pengungkapan Sukarela Dampaknya terhadap Biaya Modal Ekuitas Melalui Asimetri Informasi Ibnu Abni Lahaya

Sofian, S., Siti Zaleha, A.R., Mehri, M., \& Amir. M. A. 2011. Moderating Effect of Intellectual Capital on Relevance of Earnings and Cost of Equity Relationship: Review of Contemporary Literature. Australian Journal of Basic and Applied Sciences Vol. 5 (9): 1633-1639.

Suwardjono. 2010. Teori Akuntansi: Perekayasaan Pelaporan Keuangan. Edisi Ketiga. BPFE Yogyakarta.
Utami, W. 2005. Pengaruh Manajemen Laba terhadap Biaya Modal Ekuitas: Studi pada Perusahaan Publik Sektor Manufaktur. Simposium Nasional AkuntansiVIII Solo, 15-16 September 2005.

Wang, J. 1993, A Model of Intertemporal Asset Pricing Under Asymmetric Information, TheReview of Economic Studies, 60(2): 249-282. 